\title{
Impact of Knowledge Management on Employee Work Performance: Evidence from Saudi Arabia
}

\author{
Dr. Bader Alyoubi \\ Department of Management Information Systems, College of Business, University of Jeddah \\ balyoubi@uj.edu.sa \\ Dr. Md. Rakibul Hoque \\ Department of Management Information Systems, Faculty of Business Studies, University of Dhaka \\ rakibul@du.ac.bd \\ Dr. Ibraheem Alharbi \\ Department of Management Information Systems, College of Business, University of Jeddah \\ imalharbi@uj.edu.sa \\ Dr. Adel Alyoubi \\ Department of Management Information Systems, College of Business, University of Jeddah \\ aaaalyoubi@uj.edu.sa \\ Dr. Najah Almazmomi \\ Department of Management Information Systems, College of Business, University of Jeddah \\ nalmazmomi@uj.edu.sa
}

\begin{abstract}
Knowledge Management (KM) has become critical in today's highly competitive, uncertain, and rapidly changing business environment. The objective of this study is to measure the effects of knowledge management processes (knowledge acquisition, knowledge sharing, knowledge creation and knowledge retention) and knowledge management approaches (social networks, codification and personalization) on job satisfaction and examines how they increase employees' work performance. A theoretical model based on KM processes and approaches is proposed. It is empirically tested with structural equation modeling (SEM) and partial least squares (PLS) of survey data collected from employees of the King Fahd National Library in Jeddah, Saudi Arabia. The analysis showed that there is a significant and positive impact of $\mathrm{KM}$ processes and approaches on job satisfaction and work performance. Knowledge sharing, knowledge retention, codification and personalization approaches have significant impacts on job satisfaction, and knowledge acquisition, knowledge creation and a social network approach have no significant impacts on job satisfaction. Managers are advised to implement KM activities in their organizations to improve knowledge worker performance and the welfare of employees at work. This is the first study that theoretically examines the effect of knowledge management processes and knowledge management approaches on 'soft' human issues such as the job satisfaction and work performance of individual employees in an academic library.
\end{abstract}

Keywords: Knowledge Management, Saudi Arabia, Work Performance.

Copyright (C) 2018, the Authors. Published by Atlantis Press.

This is an open access article under the CC BY-NC license (http://creativecommons.org/licenses/by-nc/4.0/). 


\section{Introduction}

Knowledge Management (KM) has become a critical element in today's highly competitive, uncertain, and rapidly changing business environment. $\mathrm{KM}$ is the process of accessing experience, knowledge, and expertise that produces new skills, enables work performance, encourages innovation and creates customer value. ${ }^{1}$ It creates a favorable environment for knowledgeable individuals to use and share their expertise and knowledge and create new knowledge. From a knowledge-based point of view, the most fundamental means of production are intangible; it is focused on human capital, i.e., the skills, experiences, competences, motivation for work, and the manner in which they use these skills for the benefit of the organization. ${ }^{2}$

As human knowledge, skills, and intelligence are tacit and individually centered, they are not easily captured and processed for the benefit of the organization. This can be a challenge for management in some cases. Knowledge management is a core field of society based on information and knowledge resources, and the library has emerged as a significant part of this field. ${ }^{3}$ Libraries are widely recognized as knowledgebased organizations that primarily focus on collecting, processing and distributing knowledge and information services for different stakeholders. ${ }^{4}$ This means that knowledge is considered their primary resource, and thus, improving KM practice and enabling knowledge are a challenge in libraries. 5,6 Research has shown that $\mathrm{KM}$ processes and approaches influence job satisfaction, which ultimately fosters employee work performance.

Many prior studies broadly explained that job satisfaction is an employee's positive/negative perception associated with his/her job ${ }^{7}$, which fosters organizational commitment and work performance as final outputs. 8,7 The antecedents of job satisfaction have been studied widely, and several essential factors have been identified, such as job design, skill variety, and role ambiguity. ${ }^{9}$ However, KM issues have not been included among the observed influencing factors. Though job satisfaction is the most researched topic in the field of organizational behavior ${ }^{10,7}$, it has rarely been approached from a knowledge-based perspective. To bridge this gap in the literature, this paper examines how KM process and approaches work to influence the satisfaction of individual employees with their jobs.
The impact of KM processes and approaches on job satisfaction and work performance has been discussed very rarely in the literature. ${ }^{11,12,13}$ However, for several reasons, this study is significant and unique. First, we investigate the effect of KM from two points of view, its operations and its approaches, as there is a gap in examining the effects of these two disciplines on the measurement of job satisfaction and performance in Saudi Arabian Libraries. Second, this study is a new contribution as it emphasizes examination of both KM processes and approaches in a new context in Saudi Arabia (Academic Libraries).

\section{Theoretical Background}

\subsection{Job Satisfaction}

According to Spector ,7 "job satisfaction can be defined as the degree to which people have satisfaction or dissatisfaction related to their jobs". The concept of job satisfaction can contribute to psychological well-being at work. ${ }^{14}$ The meaning of job satisfaction differs ${ }^{15}$ from the feelings a worker has about his/her job16 to "an effective reaction to a job, which results from the incumbent's comparison of actual outcomes with those that are desired". 17

Job satisfaction has a strong positive connection with organizational commitment ${ }^{18}$, work performance ${ }^{19,20}$, and organizational culture ${ }^{21}$ and is discussed broadly in the existing literature. However, few existing studies have discussed $\mathrm{KM}$ processes as they relate to job satisfaction and work performance $22,23,13$. Additionally, the impacts of KM approaches on job satisfaction and work performance have not been properly explored.

\subsection{Knowledge management processes}

" $\mathrm{KM}$ is the process of access to experience, knowledge, and expertise that produce new skills, enable work performance, encourage innovation and create customer value". ${ }^{1}$ Typically, KM is a knowledge process comprising knowledge creation, sharing, acquisition, transfer and application with infrastructures, skills and top management support that encourage and enhance KM processes. ${ }^{24,25}$

The existing literature on $\mathrm{KM}$ categorized the $\mathrm{KM}$ process into six parts: knowledge acquisition, knowledge sharing, knowledge creation, knowledge 
codification, knowledge application/use, and knowledge retention. 26,27,28 However, these types of knowledge processes are cyclically interrelated. Therefore, this paper proposes that KM processes can be divided into four individually distinguishable types, i.e., knowledge acquisition, knowledge sharing, knowledge creation, and knowledge retention. These four KM processes are briefly explained below.

The first step of the KM process is knowledge acquisition. This refers to searching for, identifying, selecting, collecting, organizing and mapping information/knowledge ${ }^{29}$. Tiwana ${ }^{30}$ defined knowledge acquisition as the process of development and creation of insights, skills and relationships. Choo defined ${ }^{31}$ "knowledge generation or acquisition as the activities that increase the stock of organizational knowledge". According to Wilfredo Bohorquez Lopez and Esteves ${ }^{32}$, knowledge acquisition can be enabled through an organization's external and internal networks to promote employee self-actualization within the organization to make employees more motivated and more committed and to improve their work satisfaction. For example, customer feedback systems, data mining, business intelligence and collaboration with partners and research institutions are characteristic highly developed knowledge acquisition practices.

Tacit knowledge is rooted in human expertise and shared in social interaction. Although some tacit knowledge may be codified, much remains implicit as the only way to share it is through face-to-face interaction $^{28}$; knowledge sharing is the key for managing tacit knowledge. The power of knowledge is increased by sharing it through disseminating and using what is already known. Lee, Lee, and Kang ${ }^{33}$ defined knowledge sharing as promoting dissemination of knowledge to make the work process effective and knowledge-intensive, as knowledge workers capture the necessary knowledge from several sources and confirm the integration of these sources in a manner that leads to improved performance and completion of employees' tasks successfully. Therefore, organizations should encourage frequent face-to-face communication and the creation of shared learning experiences and build a knowledge-sharing culture. $34,35,28$ Knowledge-sharing activities include informal communication, brainstorming sessions, mentoring and coaching. ${ }^{36}$

Obeidat et al. ${ }^{12}$ noted that there is a strong relation between propensity for knowledge sharing and individual work performance in service organizations; when employees are encouraged to distribute knowledge within organizations, it enhances their ability to generate and to create new ideas. Kianto et al. 11 noted that knowledge sharing and job satisfaction are highly correlated and improve employee work performance. Thus, knowledge sharing is necessary for all organizations and is especially critical for the functioning and management of academic libraries, as knowledge is the main block of the services provided ${ }^{6}$

Knowledge creation refers to an organization's ability to develop new and useful ideas and solutions for various aspects of organizational activities, from products and technological processes to managerial practices.11,28 Knowledge is created when an organization and its members learn and innovate. Knowledge-creating organizations arrange for the development of potential and self-transcending knowledge to cultivate radically new insights ${ }^{36}$ and promote innovation and idea development at all levels of the organization.

Finally, knowledge retention refers to activities related to managing personnel turnover and the associated loss of expert knowledge - a key strategic resource. ${ }^{11}$ Expert knowledge can be lost when employees leave the organization due to job dissatisfaction..$^{20}$ As baby boomers retire, attracting and maintaining the best employees will become an even more pressing challenge in knowledge retention.

\subsection{Knowledge management approaches}

Knowledge management approaches vary from organization to organization. These approaches can be informal (social networks) or formal (codification and personalization). ${ }^{37}$ Swan and Newell ${ }^{38}$ explore these approaches as models, namely, the community model and the cognitive model. Hansen, Nohria, and Tierney 39 classified only the two most common approaches: codification and personalization. Powell and Ambrosini $^{37}$ suggested that a KM approach is a pluralistic approach, which results in knowledge searchers using KM systems for more general knowledge and calling on coworkers to provide specific knowledge. Hansen, Nohria, and Tierney ${ }^{39}$ suggested that organizations should focus on either the personalization or codification strategy and claimed that it is better to focus on one approach than to distribute 
resources to both approaches. Powell and Ambrosini 37 stated that within the social network approach, knowledge is transmitted by contacting a person directly, whereas the codification approach requires that individuals document their knowledge and collection of the knowledge into a searchable electronic KM system that allows workers to access the knowledge base without knowing or contacting the provider of the knowledge. The personalization approach is a formalization of social networks; rather than contacting someone within their social network, he/she would consult the personalization tool and contact the ideal person for the desired knowledge. ${ }^{12}$

Tiwana $^{30}$ stated that the personalization approach improves solutions when a company faces unique problems that rely on tacit knowledge and expertise. Obeidat et al. ${ }^{12}$ noted that personalization and codification approaches positively influence employee innovation practices in the service sector, which results in motivation and creation of positive feelings towards jobs. Similarly, online communication via social networks, off-work conversation among employees inside and outside the office, and strong bonding increase knowledge sharing processes that positively influence an employee's perception towards their job and working environment.

\section{The research model and hypothesis}

Although antecedents of job satisfaction have been widely studied, ${ }^{9} \mathrm{KM}$ issues have not been included among the many job satisfaction factors examined. KM literature has rarely addressed the impact of $\mathrm{KM}$ on employee work performance through increasing job satisfaction.

As noted above, there is a dearth in the existing literature on KM and employee job satisfaction. ${ }^{13,22,40}$ Recently, Kianto et al. ${ }^{11}$ tested the relationship between KM processes and job satisfaction with 824 samples from a Finnish municipal organization. They found that KM processes have a strong impact on job satisfaction, as knowledge sharing within an organization appears to be a key KM process that increases an individual's job satisfaction. Lee and Chang ${ }^{40}$ examined the relationship between employee job satisfaction and $\mathrm{KM}$ in an electric wire and cable group in Taiwan. The results of their study revealed that job satisfaction and KM are positively correlated. Singh and Sharma ${ }^{13}$ conducted comprehensive research on Indian telecommunication industries and noted that KM was positively linked with employee job satisfaction. Almahamid et al.22 demonstrated that knowledge sharing practices in a Jordanian organization significantly impacted employees' job satisfaction. Koseoglu et al. ${ }^{23}$ noted a significant relationship between KM (knowledge sharing and knowledge transfer) and job satisfaction among 154 five-star hotel employees in Turkey.

$\mathrm{KM}$ processes comprise contextual features of the work environment, which can enrich the job and increase job satisfaction. ${ }^{41} \mathrm{KM}$ processes in organizations help employees in knowledge-intensive atmospheres establish a shared understanding and obtain value from knowledge. ${ }^{42}$ Knowledge acquisition involves access to new knowledge that improves efficiency in carrying out an individual's tasks, and knowledge sharing involves sharing acquired knowledge among employees and enriching employees' social needs to improve job satisfaction and increase job performance. Knowledge-creation processes enable individuals to participate in the planning and design of activities, utilizing their creativity. Knowledge retention increases the sense of recognition and appreciation of the employee because it is based on recognizing the value of the individual's expert knowledge. Therefore, we assume that employees will be more satisfied with their jobs relative to the level that they practice KM processes in their working environment. This discussion can be divided into four specific hypotheses:

\section{H1. Knowledge acquisition has a positive effect on job satisfaction.}

H2. Knowledge sharing has a positive effect on job satisfaction.

H3. Knowledge creation has a positive effect on job satisfaction.

H4. Knowledge retention has a positive effect on job satisfaction.

Furthermore, KM approaches including social networking, personalization, and codification have strong influences on innovation and work performance. 12 Due to the strong influence of social networks and customized information sharing, employees become more socially involved within or outside organizations. 37 The codification approach requires that individuals document their knowledge and collection of the knowledge in a central location for use and sharing on 
demand. ${ }^{37}$ Knowledge codification helps employees find the information to carry out their tasks in a timely and effective manner. ${ }^{11}$ No existing study explores the impact of KM processes and KM approaches on job satisfaction and employee work performance. Therefore, this study proposes the following hypotheses:

H5: Social networking has a positive effect on job satisfaction.

H6: Codification has a positive effect on job satisfaction.

H7: Personalization has a positive effect on job satisfaction.

The research model is depicted in Figure 1. This paper argues that the five facets of $\mathrm{KM}$ - knowledge acquisition, knowledge creation, knowledge sharing, knowledge retention, social networks, knowledge codification, and personalization improve the likelihood of employee job satisfaction. Job satisfaction, in turn, is related to high work performance. ${ }^{43,44}$ Kianto et al. ${ }^{11}$ agreed that job satisfaction has a positive relation with job performance but did not test this effect in their study. We hypothesize the following:

H8: Job satisfaction has a positive effect on individuals' work performance.

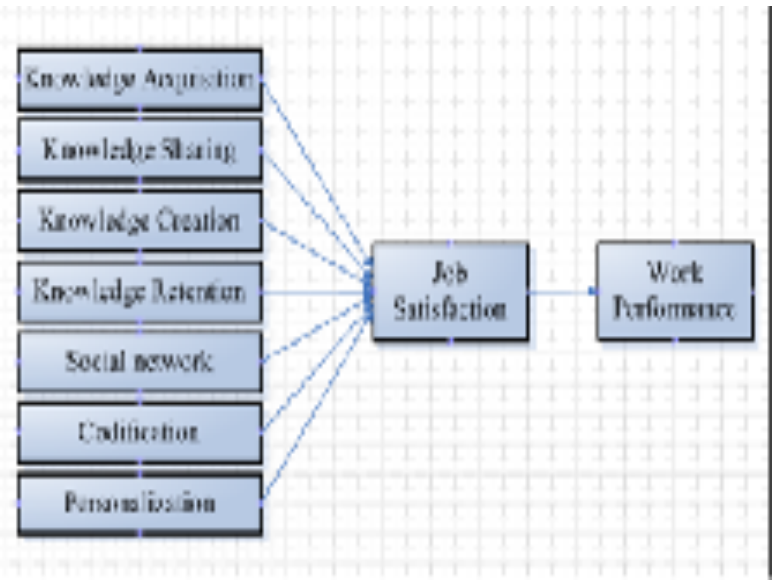

Fig. 1. Research Model

\section{Methodology}

\subsection{Measurement Instruments}

To ensure the validity of the constructs, the measurement items for the latent variables in the proposed model were developed from prior studies..$^{11,12}$ The items in each construct and their sources are listed in Table 1.

Table 1. Measurement Items

\begin{tabular}{|c|c|c|}
\hline Construct & Items & Sources \\
\hline \multirow[t]{3}{*}{$\begin{array}{l}\text { Knowledge } \\
\text { acquisition }\end{array}$} & $\begin{array}{l}\text { I easily find information } \\
\text { needed in my work from } \\
\text { sources outside my } \\
\text { organization. }\end{array}$ & \multirow[t]{3}{*}{$\begin{array}{l}\text { Henttonen et } \\
\text { al. }{ }^{45} \text {, Kianto } \\
\text { et al. }{ }^{11} \text {, } \\
\text { Obeidat et al. } \\
12\end{array}$} \\
\hline & $\begin{array}{l}\text { I obtain important } \\
\text { information from } \\
\text { collaboration partners } \\
\text { outside my organization. }\end{array}$ & \\
\hline & $\begin{array}{l}\text { I continually gather } \\
\text { information that is } \\
\text { relevant to my } \\
\text { operations and activities. }\end{array}$ & \\
\hline \multirow[t]{4}{*}{$\begin{array}{l}\text { Knowledge } \\
\text { sharing }\end{array}$} & $\begin{array}{l}\text { Communication with } \\
\text { other members of my } \\
\text { work group is efficient } \\
\text { and beneficial. }\end{array}$ & \multirow[t]{4}{*}{$\begin{array}{l}\text { Henttonen et } \\
\text { al. }{ }^{45} \text { Kianto et } \\
\text { al. }{ }^{11} \text {, Obeidat } \\
\text { et al. }{ }^{12}\end{array}$} \\
\hline & $\begin{array}{l}\text { My colleagues are } \\
\text { interactive and exchange } \\
\text { ideas widely across the } \\
\text { organization. }\end{array}$ & \\
\hline & $\begin{array}{l}\text { I find it easy to } \\
\text { communicate and co- } \\
\text { operate with employees } \\
\text { from ot he r } \\
\text { organizational units and } \\
\text { functions. }\end{array}$ & \\
\hline & $\begin{array}{l}\text { I share information and } \\
\text { learn from others. }\end{array}$ & \\
\hline \multirow[t]{2}{*}{$\begin{array}{l}\text { Knowledge } \\
\text { creation }\end{array}$} & $\begin{array}{l}\text { Information about the } \\
\text { status, results and } \\
\text { problems of different } \\
\text { projects is readily } \\
\text { available to me. }\end{array}$ & \multirow[t]{2}{*}{$\begin{array}{l}\text { Henttonen et } \\
\text { al. }{ }^{45} \text {; Kianto } \\
\text { et al. }{ }^{11} \text {, } \\
\text { Obeidat et al. } \\
12\end{array}$} \\
\hline & $\begin{array}{l}\text { My organization } \\
\text { constantly gathers } \\
\text { information about the } \\
\text { external operating } \\
\text { environment. }\end{array}$ & \\
\hline
\end{tabular}




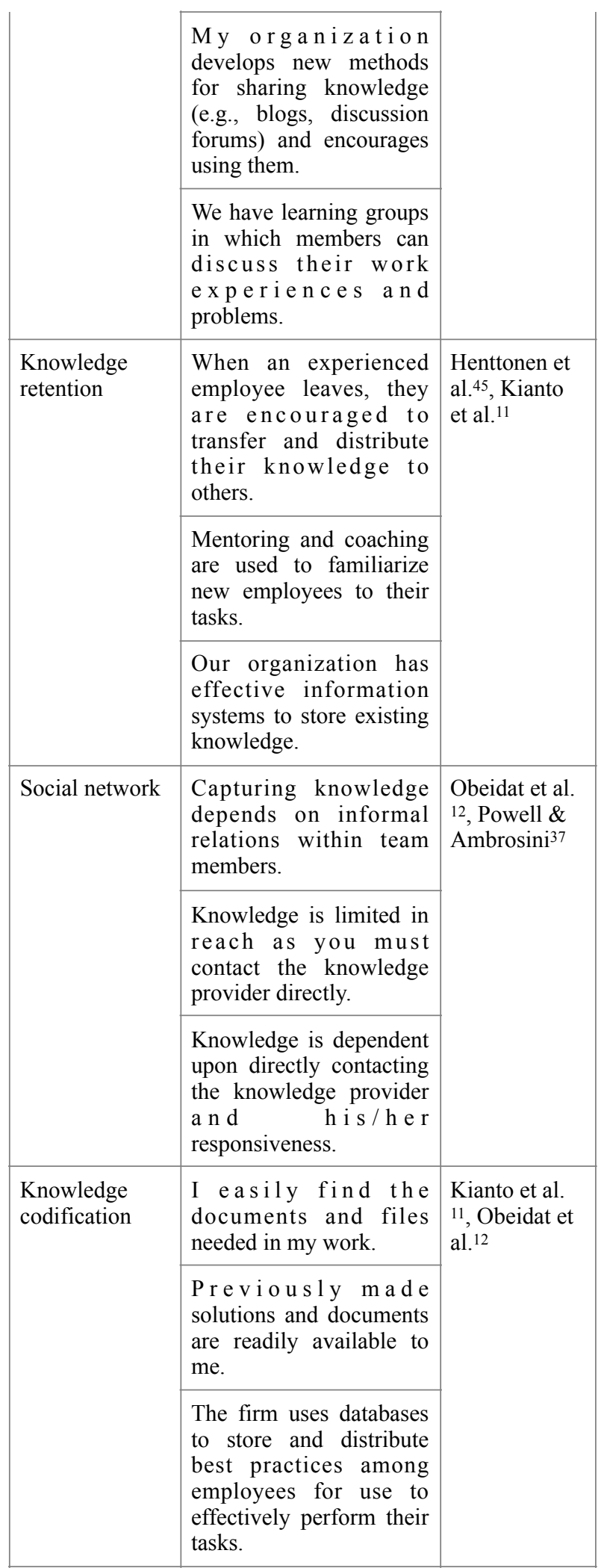

\begin{tabular}{|c|c|c|}
\hline \multirow[t]{4}{*}{ Personalization } & $\begin{array}{l}\text { I provide creative, } \\
\text { rigorous and highly } \\
\text { customized services. }\end{array}$ & \multirow[t]{4}{*}{$\begin{array}{l}\text { Obeidat et al. } \\
12, \text { Powell \& } \\
\text { Ambrosini }^{37}\end{array}$} \\
\hline & $\begin{array}{l}\text { Every problem has a } \\
\text { high chance of being a } \\
\text { "one-off" and unique } \\
\text { problem that requires } \\
\text { customized consulting } \\
\text { services and solutions. }\end{array}$ & \\
\hline & $\begin{array}{l}\text { I focus on competition } \\
\text { through providing } \\
\text { distinctive and } \\
\text { customized services. }\end{array}$ & \\
\hline & $\begin{array}{l}\text { I am rewarded for } \\
\text { directly sharing } \\
\text { knowledge with our } \\
\text { colleagues and for } \\
\text { assisting colleagues in } \\
\text { other locations/offices } \\
\text { with our problems. }\end{array}$ & \\
\hline \multirow[t]{3}{*}{ Job satisfaction } & $\begin{array}{l}\text { I enjoy my work very } \\
\text { much. }\end{array}$ & \multirow[t]{3}{*}{ Kianto et al. ${ }^{12}$} \\
\hline & $\begin{array}{l}\text { I have the opportunity to } \\
\text { apply my knowledge, } \\
\text { skills, and expertise. }\end{array}$ & \\
\hline & $\begin{array}{l}\text { There is a lot of room for } \\
\text { improvement in the } \\
\text { satisfaction of our work } \\
\text { community. }\end{array}$ & \\
\hline \multirow{3}{*}{$\begin{array}{l}\text { Work } \\
\text { performance }\end{array}$} & I am sincere in my work. & \multirow{3}{*}{$\begin{array}{l}\text { Henttonen et } \\
\text { al. }{ }^{45}\end{array}$} \\
\hline & $\begin{array}{l}\text { I make only minor } \\
\text { mistakes in my work. }\end{array}$ & \\
\hline & $\begin{array}{l}\text { I prefer team work and } \\
\text { collaboration with other } \\
\text { colleagues. }\end{array}$ & \\
\hline
\end{tabular}

\subsection{Questionnaire Design and Data Collection}

A structured questionnaire was originally developed in English and translated into the local language (Arabic) by professional translator. The translated questionnaire was translated back into English by another professional translator. Based on this double translation process ${ }^{46}$, slight corrections were made to the questionnaire to ensure that the meanings of all items remained the same during translation. Two Professors from Jeddah University in Saudi Arabia with an excellent command of the English language and knowledge of $\mathrm{KM}$ reviewed the survey questionnaires in both languages for clarity of instructions, content validity, and 
consistency before a pilot study was conducted. Some items were reworded to improve readability and comprehension. The questionnaire was divided into Part A and Part B. Part A contains demographic information regarding the respondent's age, gender, educational qualifications, and IT usage experience. Part B includes questions for the different constructs included in the proposed research model, shown in Figure 1, using a 5point Likert scale ranging from (1) "strongly disagree" to (5) "strongly agree". $47,48,49$

The first portion of the research involved a pilot study. This pilot study was conducted with 10 employees of the King Fahd National Library in Jeddah, Saudi Arabia to test the appropriateness of the questionnaire. The second portion of the research applied the revised questionnaire to the employees of King Fahd National Library in Jeddah, Saudi Arabia. One hundred fifteen questionnaires were collected, and 11 were discarded due to invalid or incomplete responses. One hundred and four valid responses were used in the analysis.

\subsection{Data Analysis}

The Partial Least Squares (PLS) method, a statistical analysis technique based on the Structural Equation Modeling (SEM), was used to test and validate the proposed model and the relationships among the hypotheses in the research model.50 SEM is a widely accepted model used to measure the validity of theories with empirical data. ${ }^{51}$ SEM has been largely utilized in business $^{52}$ and marketing 53 and has become a standard analysis technique in information systems research. ${ }^{54}$ SmartPLS 3 software was used for the statistical analyses.

\section{Results}

\subsection{Demographic Profile of Respondents}

The demographic characteristics of the respondents are shown in Table 2. Of 104 respondents, $80 \%$ were male, and $20 \%$ were female. Most respondents (40\%) were between 40 and 50 years old, and $33 \%$ of respondents had a Masters degree. In terms of position, most were mid-level employees, with $52 \%$ having more than 10 years of Internet or computer usage experience.
Table 2. Respondent Demographics.

\begin{tabular}{|c|c|c|c|}
\hline Descriptor & & Frequency & Percentage \\
\hline \multirow{2}{*}{ Gender } & Male & 83 & $80 \%$ \\
\hline & Female & 21 & $20 \%$ \\
\hline \multirow{5}{*}{ Age } & Less than 30 & 4 & $4 \%$ \\
\hline & $30-40$ & 14 & $14 \%$ \\
\hline & $40-50$ & 42 & $40 \%$ \\
\hline & $50-60$ & 24 & $23 \%$ \\
\hline & More than 60 & 20 & $19 \%$ \\
\hline \multirow{5}{*}{$\begin{array}{l}\text { Education } \\
\text { Qualificatio } \\
n\end{array}$} & $\begin{array}{l}\text { B e } 1 \text { o w } \\
\text { bachelor }\end{array}$ & 9 & $9 \%$ \\
\hline & Bachelor & 31 & $30 \%$ \\
\hline & Masters & 34 & $33 \%$ \\
\hline & $\mathrm{PhD}$ & 22 & $21 \%$ \\
\hline & Others & 8 & $7 \%$ \\
\hline \multirow{3}{*}{ Position } & $\begin{array}{l}\text { Op er at i o n } \\
\text { level }\end{array}$ & 11 & $11 \%$ \\
\hline & Mid-level & 78 & $75 \%$ \\
\hline & Top level & 15 & $14 \%$ \\
\hline \multirow{4}{*}{$\begin{array}{l}\text { I T Us age } \\
\text { Experience }\end{array}$} & $\begin{array}{l}\text { Less than } 3 \\
\text { years }\end{array}$ & 16 & $15 \%$ \\
\hline & 3-6 years & 15 & $14 \%$ \\
\hline & $7-10$ years & 19 & $19 \%$ \\
\hline & $\begin{array}{l}\text { More than } 10 \\
\text { years }\end{array}$ & 54 & $52 \%$ \\
\hline
\end{tabular}

\subsection{Measurement Model}

The measurement model was assessed by examining the internal reliability, convergent validity, and discriminant validity. ${ }^{53}$ Cronbach's Alpha $(\alpha)$ and the composite reliability $(\mathrm{CR})$ were used to assess the reliability of the constructs. The $\alpha$ and $\mathrm{CR}$ of each construct should exceed 0.70 to confirm the internal reliability of the study. ${ }^{53}$ The Cronbach's Alpha $(\alpha)$ values ranged from 0.706 to 0.839 , and the CR values ranged from 0.820 to 0.903 , as shown in Table 3, which indicates strong internal reliability. The average variance extracted (AVE) and item loadings were used to assess the 
convergent validity. ${ }^{55}$ The square root of the AVE and a cross loading matrix were used to assess the discriminant validity. ${ }^{56}$ An average variance extracted (AVE) and item loadings of 0.50 or greater indicate convergent validity. ${ }^{55}$ As shown in Table 3, the item loadings ranged from 0.675 to 0.903 , and the average variance extracted ranged from 0.537 to 0.757 , greater than the recommended threshold. Therefore, the condition of convergent validity of the measurement instruments was satisfied in this study.

Table 3. Measurement Model

\begin{tabular}{|c|c|c|c|c|c|}
\hline Construct & Items & Loadings & $\begin{array}{l}\text { Cronba } \\
\text { c h ' s } \\
\text { Alpha }\end{array}$ & $\mathrm{CR}$ & AVE \\
\hline \multirow[t]{3}{*}{ Job Satisfaction } & JS1 & 0.831 & \multirow[t]{3}{*}{0.839} & \multirow[t]{3}{*}{0.903} & \multirow[t]{3}{*}{0.757} \\
\hline & JS2 & 0.903 & & & \\
\hline & JS3 & 0.875 & & & \\
\hline \multirow{3}{*}{$\begin{array}{l}\text { K n ow } 1 \text { e d g e } \\
\text { Acquisition }\end{array}$} & KA1 & 0.890 & \multirow[t]{3}{*}{0.837} & \multirow[t]{3}{*}{0.901} & \multirow[t]{3}{*}{0.752} \\
\hline & KA2 & 0.861 & & & \\
\hline & KA3 & 0.851 & & & \\
\hline \multirow{4}{*}{$\begin{array}{l}\text { K n ow l e d g e } \\
\text { Creation }\end{array}$} & $\mathrm{KC} 1$ & 0.808 & \multirow[t]{4}{*}{0.802} & \multirow[t]{4}{*}{0.863} & \multirow[t]{4}{*}{0.613} \\
\hline & $\mathrm{KC} 2$ & 0.750 & & & \\
\hline & $\mathrm{KC} 3$ & 0.852 & & & \\
\hline & $\mathrm{KC} 4$ & 0.713 & & & \\
\hline \multirow{3}{*}{$\begin{array}{l}\text { K n ow } 1 \text { e d g e } \\
\text { Codification }\end{array}$} & KO1 & 0.810 & \multirow[t]{3}{*}{0.717} & \multirow[t]{3}{*}{0.842} & \multirow[t]{3}{*}{0.641} \\
\hline & $\mathrm{KO} 2$ & 0.859 & & & \\
\hline & $\mathrm{KO} 3$ & 0.727 & & & \\
\hline \multirow{3}{*}{$\begin{array}{l}\text { K n ow l e d g e } \\
\text { Retention }\end{array}$} & KR1 & 0.837 & \multirow[t]{3}{*}{0.732} & \multirow[t]{3}{*}{0.848} & \multirow[t]{3}{*}{0.651} \\
\hline & KR2 & 0.834 & & & \\
\hline & KR3 & 0.748 & & & \\
\hline \multirow{4}{*}{$\begin{array}{l}\text { K n ow le d g e } \\
\text { Sharing }\end{array}$} & KS1 & 0.736 & \multirow[t]{4}{*}{0.766} & \multirow[t]{4}{*}{0.851} & \multirow[t]{4}{*}{0.589} \\
\hline & $\mathrm{KS} 2$ & 0.734 & & & \\
\hline & KS3 & 0.837 & & & \\
\hline & KS4 & 0.757 & & & \\
\hline \multirow[t]{4}{*}{ Personalization } & PE1 & 0.767 & \multirow[t]{4}{*}{0.713} & \multirow[t]{4}{*}{0.822} & \multirow[t]{4}{*}{0.537} \\
\hline & PE2 & 0.782 & & & \\
\hline & PE3 & 0.701 & & & \\
\hline & PE4 & 0.675 & & & \\
\hline
\end{tabular}

\begin{tabular}{|l|l|l|l|l|l|}
\hline $\begin{array}{l}\text { S o c i a 1 } \\
\text { Networks }\end{array}$ & SN1 & 0.850 & 0.706 & 0.820 & 0.554 \\
\cline { 2 - 4 } & SN2 & 0.836 & & & \\
\cline { 2 - 4 } & SN3 & 0.828 & & & \\
\hline \multirow{2}{*}{$\begin{array}{l}\text { W o r k k } \\
\text { Performance }\end{array}$} & WP1 & 0.807 & 0.812 & 0.888 & 0.727 \\
\cline { 2 - 4 } & WP2 & 0.885 & & & \\
\cline { 2 - 4 } & WP3 & 0.863 & & & \\
\hline
\end{tabular}

The discriminant validity was assessed by the square root of the average variance extracted and the crossloading matrix and the Heterotrait-Monotrait ratio (HTMT). ${ }^{56}$ As shown in Table 4, the square root of the average variance extracted of each construct (bolded) is greater than its correlation with the other constructs. This confirms that the discriminant validity of the data was satisfied.56 Similarly, the Heterotrait-Monotrait (HTMT) calculates a ratio of the averages of the correlations of the indicators across constructs dividing by the correlations of the indicators within the same construct. ${ }^{56}$ A maximum threshold of 0.9 is suggested in the literature. Table 5 in shows the HTMT matrix in which values lower than 0.9 indicate satisfactory discriminant validity. All constructs are below the threshold and thus show acceptable discriminant validity.

Table 4: Correlation matrix and square root of the AVE

\begin{tabular}{|l|r|r|l|l|l|l|l|l|l|}
\hline & \multicolumn{1}{|l|}{ JS } & \multicolumn{1}{l|}{ KA } & KC & KO & KR & KS & PE & SN & WP \\
\hline JS & $\mathbf{0 . 8 7 0}$ & & & & & & & & \\
\hline KA & 0.316 & $\mathbf{0 . 8 6 7}$ & & & & & & & \\
\hline KC & -0.196 & -0.003 & $\mathbf{0 . 7 8 3}$ & & & & & & \\
\hline KO & 0.670 & 0.302 & -0.174 & $\mathbf{0 . 8 0 1}$ & & & & & \\
\hline KR & 0.738 & 0.365 & -0.107 & 0.530 & $\mathbf{0 . 8 0 7}$ & & & & \\
\hline KS & 0.584 & 0.316 & -0.033 & 0.475 & 0.439 & $\mathbf{0 . 7 6 7}$ & & & \\
\hline PE & 0.675 & 0.358 & -0.098 & 0.584 & 0.585 & 0.554 & $\mathbf{0 . 7 3 3}$ & & \\
\hline SN & 0.678 & 0.372 & 0.037 & 0.598 & 0.709 & 0.455 & 0.544 & $\mathbf{0 . 7 4 5}$ & \\
\hline WP & 0.817 & 0.196 & -0.168 & 0.534 & 0.612 & 0.400 & 0.597 & 0.509 & $\mathbf{0 . 8 5 2}$ \\
\hline
\end{tabular}

Note: JS $=$ Job Satisfaction, $\mathrm{KA}=$ Knowledge Acquisition, $\mathrm{KC}=$ Knowledge Creation, $\mathrm{KO}=$ Knowledge Codification, $\mathrm{KR}=$ Knowledge Retention, $\mathrm{KS}=$ Knowledge Sharing, $\mathrm{PE}=$ Personalization, $\mathrm{SN}=$ Social Networks, $\mathrm{WP}=$ Work Performance

Table 5. Heterotrait-Monotrait Ratio (HTMT)

\begin{tabular}{|l|l|l|l|l|l|l|l|l|l|}
\hline & JS & KA & KC & KO & KR & KS & PE & SN & WP \\
\hline JS & & & & & & & & & \\
\hline KA & 0.371 & & & & & & & & \\
\hline KC & 0.202 & 0.076 & & & & & & & \\
\hline
\end{tabular}




\begin{tabular}{|l|c|c|c|c|c|c|c|l|l|}
\hline KO & 0.862 & 0.375 & 0.223 & & & & & & \\
\hline KR & 0.835 & 0.470 & 0.147 & 0.722 & & & & & \\
\hline KS & 0.729 & 0.395 & 0.144 & 0.633 & 0.581 & & & & \\
\hline PE & 0.862 & 0.459 & 0.179 & 0.817 & 0.792 & 0.772 & & & \\
\hline SN & 0.834 & 0.467 & 0.189 & 0.791 & 0.865 & 0.624 & 0.713 & & \\
\hline WP & 0.885 & 0.233 & 0.169 & 0.689 & 0.784 & 0.502 & 0.764 & 0.621 & \\
\hline
\end{tabular}

\subsection{Hypothesis Testing}

The structural model was constructed to identify the path relationships among the constructs in the research model. A bootstrapping method was used to test the hypotheses at a $0.05(\mathrm{p}<0.05)$ significance level. The relationships between the dependent and independent variables were tested using path coefficient $(\beta)$ and $t$ statistics values greater than 1.96 at the $5 \%$ significance level.53 The $\mathrm{R}^{2}$ value was used to calculate the percentage of the variance explained by the independent variables in the structural model. 57

The results show that the relationships between KS and JS (KS: $t=2.458, \beta=0.189$ ), KR and JS (KR: $t=$ $3.769, \beta=0.345$ ), $\mathrm{KO}$ and JS (KO: $t=2.864, \beta=$ 0.206 ), PE and JS (PE: $t=2.364, \beta=0.171$ ), and JS and WP (KS: $t=14.676, \beta=0.813$ ) were significant at the $5 \%$ significance level. Thus, $\mathrm{H} 2, \mathrm{H} 4, \mathrm{H} 6, \mathrm{H} 7$, and $\mathrm{H} 8$ were supported in this study. However, the relationships between KA and JS (KA: $t=0.739, \beta=-0.048$ ), $\mathrm{KC}$ and JS (KC: $t=1.509, \beta=-0.104)$, and SN and JS (SN: $t=$ $1.348, \beta=0.148$ ) were insignificant. Therefore, $\mathrm{H} 1, \mathrm{H} 3$, and $\mathrm{H} 5$ were not supported in this study. Brief remarks on the hypotheses are shown in Table 6.

Table 6. Structural Model

\begin{tabular}{|c|l|c|c|c|}
\hline Hypothesis & Path & $\begin{array}{c}\text { Coefficient } \\
(\beta)\end{array}$ & $\begin{array}{c}t \text { - } \\
\text { statistic }\end{array}$ & Comments \\
\hline H1 & KA -> JS & -0.048 & 0.739 & $\begin{array}{c}\text { Not } \\
\text { Supported }\end{array}$ \\
\hline H2 & KS -> JS & 0.189 & 2.458 & Supported \\
\hline H3 & KC -> JS & -0.104 & 1.509 & $\begin{array}{c}\text { Not } \\
\text { Supported }\end{array}$ \\
\hline H4 & KR-> JS & 0.345 & 3.769 & Supported \\
\hline H5 & SN-> JS & 0.148 & 1.348 & $\begin{array}{c}\text { Not } \\
\text { Supported }\end{array}$ \\
\hline H6 & KO-> JS & 0.206 & 2.864 & Supported \\
\hline H7 & PE> JS & 0.171 & 2.364 & Supported \\
\hline H8 & JS-> WP & 0.813 & 14.676 & Supported \\
\hline
\end{tabular}

\section{Discussion}

Of the four KM processes examined in this study, knowledge sharing and knowledge retention significantly influenced the job satisfaction of the employees of the King Fahd National Library in Jeddah. The results indicate that intra-organizational knowledge sharing is the key KM process and it promotes job satisfaction for most employees. Knowledge-sharing is likely the most broadly studied aspect of the KM process, which appears to be well justified from the perspective of well-being at work. Scholastic support and encouragement and a positive work environment appear to be strong enablers of job satisfaction and high job performance. These relationships are also supported by Kianto et al. ${ }^{11}$ who found that knowledge sharing and knowledge retention positively influenced the job satisfaction of different employee groups (general employees, middle manager, and top managers) in Finland.

However, knowledge acquisition and knowledge creation are not significant factors affecting job satisfaction. These results might be a reflection of the nature of the work environment in the King Fahd National Library, which does not require knowledge acquisition (particularly from sources or partners outside the organization) or the creation of new knowledge. These activities are not encouraged by support or rewards from the library. As a result, knowledge acquisition and knowledge creation have no effect on job satisfaction; these results are consistent with the underlying concept of the work of Kianto et al.. 11

Furthermore, KM approaches (i.e., codification and personalization) also affect job satisfaction. The results indicate that the personalization approach has a strong impact on job satisfaction, which is a formal form of social networking by which employees share their knowledge and experience with the most knowledgeable employees. Personalization facilitates generation of new ideas and improvement of the quality provided to clients $^{37}$, generating more creative ideas and innovation ${ }^{58}$ and increasing innovation in the service sector. ${ }^{12}$ These results showed that use of technologies to facilitate communication, interaction and flow of knowledge between different parties will increase and enhance job satisfaction.

The results of the study also indicate that the knowledge codification approach increases job 
satisfaction. Codification allows access to standardized, documented information rather than generation of new ideas. ${ }^{12}$ It facilitates codifying or translating the existing knowledge base in an understandable format so that every employee can easily implement and reuse without specialized knowledge. ${ }^{37}$ It facilitates working procedures and increases employees' positive feelings towards their jobs.

The results showed that social networks did not have a significant impact on the job satisfaction of the library employees. This might reflect limited access to those already known by them, regardless of their knowledge level or the appropriateness of the knowledge that the employee is seeking. This result appears unexpected but may be appropriate to the Saudi Arabian context; this was consistent with Powell and Ambrosini ${ }^{37}$ and Obeidat et al.12. Though social networks encourage knowledge sharing to some extent, it only occurs in close employee networks, not in an overall intraorganization network. As a result, employees out of the close network feel negatively about their work, creating an unhealthy working environment.

\section{Implications for practitioners and researchers}

The results of this study indicate that KM has a strong impact on employee job satisfaction and work performance. Therefore, top managers should implement KM activities in their academic libraries to improve employee performance and well-being. The study, therefore, provides valuable guidelines to implement KM in organizations.

The main novelty of this study is to integrate KM processes and $\mathrm{KM}$ approaches together to measure job satisfaction and work performance in academic libraries. Particularly, KM processes (knowledge sharing and knowledge retention) are the two most important factors that facilitate knowledge, skill, and best practice sharing and maintain them for future employee development programs. Top managers could use these two factors to increase employees' positive feelings and foster their productivity. KM researchers also used knowledge sharing and knowledge retention to measure employees' attitudes, perceptions, and working behaviors.

Likewise, the KM approach (personalization and codification) helps managers to arrange their KM systems as much as possible to be open across the whole organization, which allows employees to share their knowledge and keeps the knowledge in an easily understandable format for future utilization. The organization needs an easy, personalized and codified approach to increasing job satisfaction. Furthermore, job satisfaction as an output of $\mathrm{KM}$ processes and $\mathrm{KM}$ approaches has a strong influence on work performance. High work performance means creating innovative ideas and increasing the knowledge base.

\section{Conclusion}

This study provides KM processes and approaches as antecedents of job satisfaction and work performance, something that has not been explored previously in academic research. The major findings are that the existence of KM processes and KM approaches in the working environment is positively related to high job satisfaction. Consequently, this study shows a unique benefit of KM for organizations, increasing value for the organization, and promotes the knowledge ecosystem. ${ }^{11,45}$ Therefore, KM processes and KM approaches as a novel organizational practice promote employee work performance. Thus, KM systems should be considered as organizational development tools to improve the conditions for employee well-being at work.

\section{Limitations and future research}

Notably, the study design was cross-sectional. Employees who feel satisfied with their jobs could potentially be more likely to engage in knowledge activities than those who do not feel as positively about their work. Determining the direction of this impact would require a longitudinal research setting. Another limitation of the study is the sample size. Future research can be conducted with a wider scope and larger sample size.

\section{References}

1. Gloet, M., \& Terziovski, M. (2004). Exploring the relationship between knowledge management practices and innovation performance. Journal of Manufacturing Technology Management, 15(5), 402-409.

2. Crook, T. R., Todd, S. Y., Combs, J. G., Woehr, D. J., \& Ketchen Jr, D. J. (2011). Does human capital matter? A meta-analysis of the relationship between human capital and firm performance: American Psychological Association

3. Asogwa, B. E. (2012). Knowledge management in academic libraries: Librarians in the 21 st century. Journal of Knowledge Management Practice, 13(2). 
4. Huang, K. (2014). Knowledge Sharing in a Third-PartyGoverned Health and Human Services Network. Public Administration Review, 74(5), 587-598.

5. Babalhavaeji, F., \& Kermani, Z. J. (2011). Knowledge sharing behaviour influences: a case of Library and Information Science faculties in Iran. Malaysian Journal of Library \& Information Science, 16(1), 1-14.

6. Srinivas, S. A. a. S. (2016). Driving Knowledge Sharing Initiatives for Enhanced Collaboration in Sultan Qaboos University (SQU) Libraries-A Case Study. Electronic Journal of Knowledge Management, 14(1).

7. Spector, P. E. (1997). Job satisfaction: Application, assessment, causes, and consequences (Vol. 3): Sage publications.

8. Judge, T. A., Thoresen, C. J., Bono, J. E., \& Patton, G. K. (2001). The job satisfaction-job performance relationship: A qualitative and quantitative review: American Psychological Association.

9. Glisson, C., \& Durick, M. (1988). Predictors of job satisfaction and organizational commitment in human service organizations. Administrative science quarterly, 61-81.

10. Appelbaum, E. (2000). Manufacturing advantage: Why high-performance work systems pay off: Cornell University Press.

11. Kianto, A., Kianto, A., Vanhala, M., Vanhala, M., Heilmann, P., \& Heilmann, P. (2016). The impact of knowledge management on job satisfaction. Journal of knowledge management, 20(4), 621-636.

12. Obeidat, B. Y., Obeidat, B. Y., Al-Suradi, M. M., AlSuradi, M. M., Masa'deh, R. e., Masa'deh, R. e., .Tarhini, A. (2016). The impact of knowledge management on innovation: An empirical study on Jordanian consultancy firms. Management Research Review, 39(10), 1214-1238.

13. Singh, A. K., \& Sharma, V. (2011). Knowledge management antecedents and its impact on employee satisfaction: a study on Indian telecommunication industries. The Learning Organization, 18(2), 115-130.

14. Robinson, M. J., Peterson, M., Tedrick, T., \& Carpenter, J. R. (2003). Job satisfaction on NCAA division III athletic directors: Impact of job design and time on task. International Sports Journal, 7(2), 46.

15. Fritzsche, B. A., \& Parrish, T. J. (2005). Theories and research on job satisfaction. Career development and counseling: Putting theory and research to work, 180-202.

16. Smith, P. C. (1969). The measurement of satisfaction in work and retirement: A strategy for the study of attitudes.

17. Cranny, C. J., Smith, P. C., \& Stone, E. F. (1992). Job satisfaction: How people feel about their jobs and how it affects their performance: Lexington Books.

18. Currivan, D. B. (2000). The causal order of job satisfaction and organizational commitment in models of employee turnover. Human resource management review, 9(4), 495-524

19. Irvine, D. M., \& Evans, M. G. (1995). Job satisfaction and turnover among nurses: integrating research findings across studies. Nursing research, 44(4), 246-253.

20. Talukder, M. S., Talukder, M. F. H., \& Alam, M. J. (2014). Job Dissatisfaction and Turnover: Bangladesh Perspective. European Journal of Contemporary Economics and Management, 183.
21. Lund, D. B. (2003). Organizational culture and job satisfaction. Journal of Business \& Industrial Marketing, 18(3), 219-236.

22. Almahamid, S., McAdams, A. C., \& Kalaldeh, T. (2010). The Relationships among Organizational Knowledge Sharing Practices, Employees' Learning Commitments, Employees' Adaptability, and Employees' Job Satisfaction: An Empirical Investigation of the Listed Manufacturing Companies in Jordan. Interdisciplinary Journal of Information, Knowledge \& Management, 5.

23. Koseoglu, M. A., Bektas, C., Parnell, J. A., \& Carraher, S. (2010). Knowledge management, organisational communication and job satisfaction: An empirical test of a five-star hotel in Turkey. International Journal of Leisure and Tourism Marketing, 1(4), 323-343.

24. Gold, A. H., \& Arvind Malhotra, A. H. S. (2001). Knowledge management: An organizational capabilities perspective. Journal of Management Information Systems, 18(1), 185-214.

25. Lee, H., \& Choi, B. (2003). Knowledge management enablers, processes, and organizational performance: An integrative view and empirical examination. Journal of management information systems, 20(1), 179-228.

26. Alavi, M., \& Leidner, D. E. (2001). Knowledge management and knowledge management systems: Conceptual foundations and research issues. MIS quarterly, 107-136.

27. Lin, R.-J., Che, R.-H., \& Ting, C.-Y. (2012). Turning knowledge management into innovation in the high-tech industry. Industrial Management \& Data Systems, 112(1), 42-63.

28. Nonaka, I. (1991). The Knowledge-Creating Company Harvard Business Review November-December.

29. Pinho, I., Rego, A., \& Pina e Cunha, M. (2012) Improving knowledge management processes: a hybrid positive approach. Journal of knowledge management, 16(2), 215-242.

30. Tiwana, A. (2000). The knowledge management toolkit. Prantice hall.

31. Choo, C. W. (2003). Perspectives on managing knowledge in organizations. Cataloging \& classification quarterly, 37(1-2), 205-220.

32. Wilfredo Bohorquez Lopez, V., \& Esteves, J. (2013). Acquiring external knowledge to avoid wheel reinvention. Journal of knowledge management, 17(1), 87-105.

33. Lee, K. C., Lee, S., \& Kang, I. W. (2005). KMPI: measuring knowledge management performance. Information \& management, 42(3), 469-482.

34. Carpenter, S., \& Rudge, S. (2003). A self-help approach to knowledge management benchmarking. Journal of knowledge management, 7(5), 82-95.

35. Dalkir, K., \& Liebowitz, J. (2011). Knowledge management in theory and practice: MIT press.

36. Otto Scharmer, C. (2001). Self-transcending knowledge: sensing and organizing around emerging opportunities. Journal of knowledge management, 5(2), 137-151.

37. Powell, T. H., \& Ambrosini, V. (2012). A pluralistic approach to knowledge management practices: Evidence from consultancy companies. Long Range Planning, 45(2), 209-226. 
38. Swan, J., \& Newell, S. (2000). Linking knowledge management and innovation. ECIS 2000 Proceedings, 173.

39. Hansen, M. T., Nohria, N., \& Tierney, T. (1999). What's your strategy for managing knowledge. The knowledge management yearbook 2000-2001, 1-10.

40. Lee, Y., \& Chang, H. (2007). Job satisfaction and knowledge management: an empirical study of a Taiwanese public listed electric wire and cable group. The Business Review, 7(2), 56-60.

41. Morgeson, F. P., \& Humphrey, S. E. (2006). The Work Design Questionnaire (WDQ): developing and validating a comprehensive measure for assessing job design and the nature of work. Journal of Applied Psychology, 91(6), 1321.

42. Mohrman, S. A., Finegold, D., \& Klein, J. A. (2002). Designing the knowledge enterprise: Beyond programs and tools. Organizational Dynamics, 31(2), 134-150.

43. Shaikh, M. A., Bhutto, N. A., \& Maitlo, Q. (2012). Facets of job satisfaction and its association with performance. International Journal of Business and Social Science, 3(7).

44. Springer, G. J. (2011). A study of job motivation, satisfaction, and performance among bank employees. Journal of Global Business Issues, 5(1), 29

45. Henttonen, K., Henttonen, K., Kianto, A., Kianto, A., Ritala, P., \& Ritala, P. (2016). Knowledge sharing and individual work performance: an empirical study of a public sector organisation. Journal of knowledge management, 20(4), 749-768.

46. Hoque, R., \& Sorwar, G. (2017). Understanding factors influencing the adoption of mHealth by the elderly: An extension of the UTAUT model. International journal of medical informatics, 101, 75-84

47. Alshibly, H., Chiong, R., \& Bao, Y. (2016). Investigating the Critical Success Factors for Implementing Electronic Document Management Systems in Governments: Evidence from Jordan. Information Systems Management, 33(4), 287-301.

48. Bao, Y., Hoque, R., \& Wang, S. (2017). Investigating the determinants of Chinese adult children's intention to use online health information for their aged parents. International journal of medical informatics, 102, 12-20.

49. Hoque, R. (2016). An empirical study of mHealth adoption in a developing country: the moderating effect of gender concern. BMC Medical Informatics and Decision Making, 16(1), 51.

50. Chin, W. W. (1998). The partial least squares approach to structural equation modeling. Modern methods for business research, 295(2), 295-336.

51. Götz, O., Liehr-Gobbers, K., \& Krafft, M. (2010). Evaluation of structural equation models using the partial least squares (PLS) approach Handbook of partial least squares (pp. 691-711): Springer.

52. Richter, N. F., Cepeda, G., \& José L. Roldán. (2015). European management research using Partial Least Squares Structural. European Management Journal, 33, 1-3.

53. Hair, J. F., Sarstedt, M., Ringle, C. M., \& Mena, J. A. (2012). An assessment of the use of partial least squares structural equation modeling in marketing research. Journal of the Academy of Marketing Science, 40(3), 414-433.
54. Rana, N. P., Dwivedi, Y. K., \& Williams, M. D. (2015). A meta-analysis of existing research on citizen adoption of e-government. Information Systems Frontiers, 17(3), 547-563.

55. Fornell, C., \& Larcker, D. F. (1981). Evaluating structural equation models with unobservable variables and measurement error. Journal of marketing research, 39-50.

56. Henseler, J., Ringle, C. M., \& Sarstedt, M. (2015). A new criterion for assessing discriminant validity in variancebased structural equation modeling. Journal of the Academy of Marketing Science, 43(1), 115-135.

57. Klarner, P., Sarstedt, M., Hoeck, M., \& Ringle, C. M. (2013). Disentangling the effects of team competences, team adaptability, and client communication on the performance of management consulting teams. Long Range Planning, 46(3), 258-286.

58. Taminiau, Y., Smit, W., \& De Lange, A. (2009). Innovation in management consulting firms through informal knowledge sharing. Journal of knowledge management, 13(1), 42-55. 